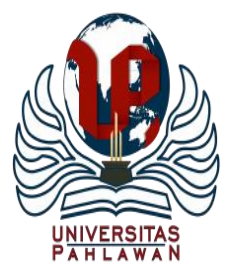

Edukatif : Jurnal Ilmu Pendidikan Volume 3 Nomor 5 Tahun 2021 Halm 2961 - 2969

EDUKATIF: JURNAL ILMU PENDIDIKAN

Research \& Learning in Education

https://edukatif.org/index.php/edukatif/index

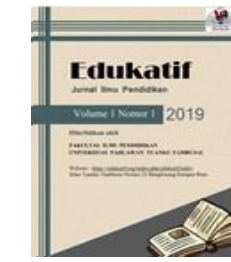

\title{
Efektivitas Penggunaan Aplikasi Zoom Meeting dalam Pembelajaran PAI di Masa Pandemi Covid-19
}

\author{
Novita $^{1 凶}$, Muhamad Taufik Bintang Kejora ${ }^{2}$, Akil $^{3}$ \\ Universitas Singaperbangsa Karawang, Indonesia ${ }^{1,2,3}$ \\ E-mail : novita0899@gmail.com ${ }^{1}, \underline{\text { muhamad.taufik@fai.unsika.ac.id }}^{2}, \underline{\text { akil@ @ai.unsika.ac.id }}^{3}$
}

\begin{abstract}
Abstrak
Sejak awal pandemic, sejalan dengan intuksi School From Home pembelajaran PAI di kelas VIII SMPN 2 Pasawahan dilaksanakan dengan memanfaatkan aplikasi Zoom. Tujuan penelitian ini adalah untuk menganalisis dan mendeskripsikan seberapa efektif penggunaan Zoom dalam pembelajaran PAI di masa pandemic. Penelitian ini merupakan penelitian deskriptif survei dengan pengumpulan data menggunakan angket berbasis Googleform berskala Likert. Subjek penelitian sebanyak 89 siswa kelas VIII SMPN 2 Pasawahan Purwakarta. Hasil penelitian menunjukkan pemanfaatan Zoom menjadikan pembelajaran PAI secara daring lebih efektif. Keterampilan guru secara bertahap meningkat dalam mengelola pembelajaran. Beberapa kendala dihadapi siswa seperti kuota, akses internet, dan ketersediaan bahan ajar. Efektivitas pembelajaran nampak pada hasil belajar dan kepuasan siswa dalam pembelajaran. Kendati demikian beberapa aspek perlu ditingkatkan terkait kemampuan siswa mereview pembelajaran, dan ketersediaan bahan ajar. Guru perlu memberikan penekanan pentingnya kedisiplinan dan kemandirian belajar sehingga siswa mampu memiliki kesadaran belajar yang lebih baik.
\end{abstract}

Kata Kunci: Efektivitas, Pembelajaran Online, Pendidikan Agama Islam, Zoom.

\begin{abstract}
Since the beginning of the pandemic, such as PAI learning at the VIII class house of SMPN 2 Pasawahan, it has been carried out using the Zoom application. The purpose of this study is to analyze and describe how effective the use of Zoom in PAI learning is during the pandemic. This research is a descriptive survey research with data collection using Googleform-based questionnaires. The research subjects were 89 students of class VIII SMPN 2 Pasawahan Purwakarta. The results of research using Zoom make PAI learning more effective. Teachers' skills are gradually increasing in managing learning. Some of the obstacles faced by students such as quotas, internet access, and the availability of teaching materials. The effectiveness of learning appears in learning outcomes and student satisfaction in learning. Thus, several aspects need to be improved related to students' ability to review learning, and the availability of learning materials. Teachers need to emphasize the importance of independent learning so that students are able to have a better awareness of learning.
\end{abstract}

Keywords: Effectiveness, Online Learning, Islamic Religious Education, Zoom.

Copyright (c) 2021 Novita, Muhamad Taufik Bintang Kejora, Akil

$\triangle$ Corresponding author

Email : novita0899@gmail.com

DOI : https://doi.org/10.31004/edukatif.v3i5.1070

ISSN 2656-8063 (Media Cetak)

ISSN 2656-8071 (Media Online)

Edukatif : Jurnal Ilmu Pendidikan Vol 3 No 5 Tahun 2021 p-ISSN 2656-8063 e-ISSN 2656-8071 
2962 Efektivitas Penggunaan Aplikasi Zoom Meeting dalam Pembelajaran PAI di Masa Pandemi Covid-19Novita, Muhamad Taufik Bintang Kejora, Akil

DOI: https://doi.org/10.31004/edukatif.v3i5.1070

\section{PENDAHULUAN}

Epidemi global Covid-19 secara dramatis mengubah lingkungan pembelajaran secara masiv dan revolusioner (Minhas et al., 2021). Pada pembelajaran PAI misalnya, pembelajaran yang biasanya sebelum pandemic diajarkan secara tatap muka sekarang harus lintas-rekayasa dilaksanakan secara online memanfaatkan plarform pembelajaran berbasis digital (Lubis et al., 2020).

Saat ini kita hidup di dunia di mana teknologi mampu membantu mempermudah berbagai pekerjaan dan aktivitas. Bahkan kemajuan teknologi mampu mempengaruhi perubahan besar dalam metodologi pedagogi di lingkungan belajar (Guzacheva, 2020). Terlebih dengan adanya pandemic Covid-19 yang mempromosikan pembelajaran jarak jauh dan belajar dari rumah (BDR), "pembelajaran online/daring" telah menjadi istilah yang mentransformasi cara guru dan siswa berinteraksi dalam pembelajaran (Sögüt et al., 2021). Lingkungan kelas di masa pandemic benar-benar berbeda dari ruang kelas tradisional dan menuntut adanya media yang memfasilitasi pembelajaran secara virtual (Butnaru et al., 2021).

Pembelajaran online/daring atau lebi dikenal dengan E-learning adalah pemanfatan jaringan teknologi informasi dan komunikasi untuk mendukung proses pengajaran dan belajar (Puspita Sari \& Setiawan, 2018). Istilah-istilah yang digunakan untuk menggambarkan pembelajaran online learning, pembelajaran berbasis web, Gaussian, pada dasarnya semua mengacu pada proses pendidikan yang memanfaatkan teknologi dalam kegiatan pembelajaran pengajaran (Putra et al., 2020). Secara garis besar definisi e-learning dikemukakan oleh (Setiawan et al., 2021) yaitu penyampaian pembelajaran materi melalui media elektronik seperti internet, internet, siaran satelit, audio/video tape, TV interaktif, CD-ROM, dan pelatihan berbasis komputer (CBT). Kemudian menurut (Puspita Sari \& Setiawan, 2018) E-learning adalah proses belajar (learning) menggunakan/memanfaatkan teknologi informasi dan komunikasi (TIK) sebagai alat yang tersedia Kapanpun dan dimanapun dibutuhkan sehingga dapat mengatasi kendala ruang dan waktu.

Kehadiran beragam aplikasi atau platform pembelajaran dan media sosial online justru muncul pula pertanyaan, media apa dan bagaimana strategi yang efektif dalam pembelajaran daring? Pasalnya ada banyak aplikasi yang tersedia di ponsel handphone yang bisa digunakan untuk belajar, seperti Line, WhatsApp, Zoom, Telegram, Google Classroom, Edmoddo, dan masih banyak lainnya (Nguyen, 2017).

Studi awal penelitian ini, menunjukkan Zoom menjadi salah satu aplikasi yang digunakan untuk mendukung dan memfasilitasi guru dan siswa dalam pembelajaran PAI di SMP Negeri 2 Pasawahan kabupaten Purwakarta. Zoom Meeting merupakan sebuah aplikasi online yang didirikan oleh Eric Yuan pada 2011 di San Jose, California, Amerika Serikat (Sadikin \& Hamidah, 2020). Pemilihan zoom sebagai teknologi pembelajaran PAI dilatarbelakangi beberapa manfaat dan keunggulan. Zoom menawarkan Free charge atau gratis biaya, dapat digunakan oleh siapapun dengan batas waktu empat puluh menit dan tidak ada batasan waktu jika akun kita berbayar. Dengan Zoom kita bisa berkomunikasi langsung dengan siapapun lewat video. Oleh karena itu, memang cocok digunakan sebagai media pembelajaran

Aplikasi Zoom memungkinkan pengguna untuk saling bertemu secara virtual. Zoom menjasi aplikasi yang cukup menarik karena memiliki fasilitas perekaman aktivitas otomatis selama menjalankan video conferencing sehingga dapat dibuat dokumen kegiatan yang nantinya diperoleh kembali dapat dilihat atau diputar ulang jika diperlukan. Dibandingkan dengan aplikasi lain, Zoom memiliki beberapa keunggulan, salah satunya adalah teknologi aplikasi Zoom berpotensi menjembatani ruang, waktu, serta fleksibilitas waktu siswa dalam pembelajarannya proses (Bawanti \& Arifani, 2021).

Beberapa penelitian mengenai pemanfaatan Zoom dalam pembelajaran menunjukkan hasil yang bervariasi. Farfar (2021) dalam hasil penelitiannya menjelaskan penggunaan zoom meeting dalam pembelajaran jarak jauh dinilai tidak efektif selama proses pembelajaran. Namun dengan mempertimbangkan situasi meningkatnya wabah Covid-19 maka penggunaan aplikasi zoom meeting menjadi sangat relevan dalam menunjang proses pembelajaran. Bertolak belakang dengan Farfar, Suardi (2020) menyimpulkan bahwa 
2963 Efektivitas Penggunaan Aplikasi Zoom Meeting dalam Pembelajaran PAI di Masa Pandemi Covid-19Novita, Muhamad Taufik Bintang Kejora, Akil

DOI: https://doi.org/10.31004/edukatif.v3i5.1070

penggunaan aplikasi ZOOM Cloud Meetings sangat efektif dalam proses pembelajaran. Pada aspek kognitif, transfer ilmu tetap berjalan seperti biasa, sama seperti proses belajar tatap muka di kelas bahkan memiliki kelebihan karena proses pembelajarannya santai. Dalam afektif aspek, siswa tetap mendapatkan suri tauladan yang baik terutama dalam hal konsistensi mengajar guru meskipun tidak dapat hadir di kelas secara tatap muka, dan pada aspek psikomotor, penggunaan ZOOM Cloud Meetings juga efektif karena siswa sebenarnya calon guru dapat mempelajari keterampilan baru yang dapat diaplikasikan pada dunia nyata.

Studi Monica \& Fitriawati (2020) mengungkap bahwa pembelajaran online menggunakan aplikasi Zoom sudah efektif, mendapat respon yang sangat baik dari siswa, penggunaannya yang fleksibel, siswa lebih mandiri dan mendorong siswa untuk lebih aktif dalam pemulihan mereka. Selain itu banyaknya fitur di dalam Zoom membuat pembelajaran menjadi lebih menarik.

Beberapa penelitian telah mengkaji kondisi dan efektivitas pembelajaran menggunakan Zoom. Namun pada penelitian ini, penulis berupaya menganalisis dan mendeskripsikan efektivitas penggunaan aplikasi zoom meeting dalam pembelajaran PAI selama masa pandemi covid-19. Subjek yang kami teliti adalah siswa pada sekolah jenjang SMP dengan akses teknologi dan kondisi geografis yang cukup jauh dari akses internet yang kuat. Diharapkan melalui penelitian ini dapat memberikan gambaran tentang kondisi objektif yang dialami oleh guru dan siswa dalam pembelajaran PAI secara online dengan memanfaatkan Zoom. Temuan penelitian diharapkan dapat menjadi bahan evaluasi bagi berbagai pihak termasuk pengambil kebijakan dan guru dalam melakukan optimalisasi pembelajaran online khususnya PAI pada jenjang SMP.

\section{METODE PENELITIAN}

Penelitian ini merupakan penelitian survei deskriptif. Metode survei merupakan suatu teknik dalam penelitian dengan pengumpulan data melalui sejumlah pertanyaan yang diarahkan kepada sejumlah orang sebagai sampel atau responden (Rahayu, 2015). Penelitian melibatkan responden 89 siswa kelas VIII SMP negeri 2 Pasawahan kabupaten Purwakarta. Pengumpulan data menggunakan angket berbantuan Googleform guna menjaga protokol kesehatan dan mengurangi kontak langsung dengan siswa (Dong et al., 2020). Angket yang digunakan adalah angket tertutup berskala guna mengukur respon siswa mengenai pembelajaran oleh guru, keterlaksanaan pembelajaran oleh siswa, hasil belajar dan kepuasan siswa menjalani pembelajaran PAI menggunakan Zoom.

Skala Likert yang digunakan mencakup; sangat baik dengan skor 5; baik dengan skor 4; cukup dengan skor 3; rendah dengan skor 2; dan sangat rendah dengan skor. Setelah data kuantitatif dikumpulkan, selanjutnya adalah menganalisa dan menentukan skor rata-rata setiap item (Creswell, 2014). Data dalam bentuk skor atau angka diidentifikasi menggunakan interval Bringula (Patacsil and Tablatin 2017; Salam 2020) dengan skala 5 poin penskoran.

Tabel 1. Interprestasi Skor Penelitian

\begin{tabular}{cccc}
\hline No & Rentang Nilai/Skor & $\%$ & Kriteria \\
\hline 1. & $1,00-1,50$ & $20,00 \%-30,00 \%$ & Sangat Rendah \\
\hline 2. & $1,51-2,50$ & $30,01 \%-50,00 \%$ & Rendah \\
\hline 3. & $2,51-3,50$ & $50,01 \%-70,00 \%$ & Cukup \\
\hline 4. & $3,51-4,50$ & $70,01 \%-90,00 \%$ & Baik \\
\hline 5. & $4,51-5,00$ & $90,01 \%-100 \%$ & Sangat Baik \\
\hline
\end{tabular}


2964 Efektivitas Penggunaan Aplikasi Zoom Meeting dalam Pembelajaran PAI di Masa Pandemi Covid-19Novita, Muhamad Taufik Bintang Kejora, Akil

DOI: https://doi.org/10.31004/edukatif.v3i5.1070

\section{HASIL DAN PEMBAHASAN PENELITIAN}

Pengumpulan data penelitian menggunakan angket online berbantuan Googleform sebagai salah satu alternatif guna mengumpulkan data di tengah kondisi pandemic Covid-19. Pengumpulan data dibantu oleh guru dan ketua siswa agar pengumpulan data terlaksana secara efektif dan efisien. Responden siswa yang terlibat dalam pengumpulan data sebanyak 89 siswa dari 5 rombel kelas yang terdiri dari 33 siswa laki-laki dan 56 siswa perempuan.

Tabel 2. Responden Survei

\begin{tabular}{ccccc}
\hline No & Kelas & Laki & Perempuan & Total \\
\hline 1 & VII A & 5 & 12 & 17 \\
\hline 2 & VIII B & 7 & 12 & 19 \\
\hline 3 & VIII C & 7 & 9 & 16 \\
\hline 4 & VIII D & 6 & 14 & 20 \\
\hline 5 & VIII E & 8 & 9 & 17 \\
\hline & \multirow{2}{*}{ Jumlah } & 33 & 56 & 89 \\
\cline { 3 - 5 } & & 37,08 & 62,92 & 100 \\
\hline
\end{tabular}

Pada bagian pembahasan ini kami deskripsikan hasil temuan penelitian kegiatan pembelajaran online memanfaatkan aplikasi zoom pada pembelajaran PAI di kelas VII SMPN 2 Pasawahan yang dapat diuraikan sebagai berikut:

\section{Guru dalam Pembelajaran PAI Memanfaatkan Aplikasi Zoom.}

Pada bagian pertama ini menjelaskan mengenai respon siswa mengenai pembelajaran PAI oleh guru memanfaatkan aplikasi Zoom. Pengumpulan data melalui angket berbantuan Googleform. Hasilnya dilaporkan sebagai berikut:

Tabel 3. Keterampilan Mengajar Guru PAI Berbantuan Zoom

\begin{tabular}{clccc}
\hline No & \multicolumn{1}{c}{ Keterampilan Mengajar } & Skor & \% & Interprestasi \\
\hline 1 & Keterampilan membuka dan menutup pelajaran & 4,28 & 85,6 & Baik \\
\hline 2 & Keterampilan bertanya & 4,69 & 93,8 & Sangat Baik \\
\hline 3 & Menjelaskan & 4,59 & 91,8 & Sangat Baik \\
\hline 4 & Mengadakan variasi pembelajaran & 3,77 & 75,4 & Baik \\
\hline 5 & Membimbing diskusi kelompok & 3,26 & 65,2 & Baik \\
\hline 6 & Mengelola kelas dengan ramah \& profesional & 3,67 & 73,4 & Baik \\
\hline 7 & Menggunakan media pembelajaran & 4,69 & 93,8 & Sangat Baik \\
\hline 8 & Mengajar kelompok kecil dan individual & 3,64 & 72,8 & Baik \\
\hline 9 & Memberi penguatan & 4,21 & 84,2 & Baik \\
\hline & Rata-Rata & 4,09 & 81,78 & Baik \\
\hline
\end{tabular}

Waryani (2021) mengatakan bahwa guru profesional perlu menguasai keterampilan mengajar dengan baik. Lebih lanjut Asmawati \& Bintang Kejora (2020) menjelaskan bahwa keterampilan mengajar tersebut mencakup a) keterampilan membuka dan menutup pelajaran; b) bertanya; c) menjelaskan; d) mengadakan variasi; e) membimbing diskusi kelompok kecil; f) mengelola kelas; g) menggunakan media pembelajaran; h) mengajar kelompok kecil dan individual; dan i) memberi penguatan.

Hasil pengumpulan data menunjukkan bahwa respon siswa mengklaim bahwa guru memiliki kemampuan yang baik dalam mengajar PAI berbantuan Zoom dengan rata-rata 4,09 atau prosentase 81,78\%. 
2965 Efektivitas Penggunaan Aplikasi Zoom Meeting dalam Pembelajaran PAI di Masa Pandemi Covid-19Novita, Muhamad Taufik Bintang Kejora, Akil

DOI: https://doi.org/10.31004/edukatif.v3i5.1070

Dari 9 aspek kemampuan mengajar penguasaan guru sangat baik dalam aspek bertanya, menjelaskan, dan penggunaan media pembelajaran. Siswa juga menilai bahwa guru memiliki kemampuan yang baik dalam 6 aspek lainnya. Hal ini membuktikan bahwa guru PAI mampu mengefektifkan pembelajaran dengan memanfaatkan aplikasi Zoom untuk proses dan tujuan pembelajaran.

\section{Siswa dalam Pembelajaran PAI Memanfaatkan Aplikasi Zoom}

Siswa merupakan subjek didik yang memiliki potensi dan karakteristik personal yang perlu dikembangkan melalui pembelajaran (Bilda \& Fadillah, 2020). Penelitian ini mengukur aktivitas siswa dalam pembelajaran PAI berbantuan pemanfaatan aplikasi Zoom. Hasil pengumpulan data sebagai berikut:

Tabel 4. Aktivitas Siswa dalam pembelajaran PAI Menggunakan Zoom

\begin{tabular}{clccc}
\hline No & Indikator Pembelajaran Siswa & $\begin{array}{c}\text { Jumlah } \\
\text { Siswa }\end{array}$ & Prosentase & Interprestasi \\
\hline 1 & Kehadiran meet tepat waktu & 62 & 69,66 & Cukup \\
\hline 2 & $\begin{array}{l}\text { Mengikuti pembelajaran dari awal sampai } \\
\text { akhir }\end{array}$ & 61 & 68,54 & Cukup \\
\hline 3 & Menyimak penjelasan guru secara seksama & 55 & 61,80 & Cukup \\
\hline 4 & Membuat catatan hasil pembelajaran & 45 & 50,56 & Cukup \\
\hline 5 & Mengumpulkan tugas tepat waktu & 72 & 80,90 & Baik \\
\hline 6 & Aktif dalam kegiatan diskusi dan tanya jawab & 46 & 51,69 & Cukup \\
\hline 7 & Melakukan review materi pembelajaran & 41 & 46,07 & Rendah \\
\hline 8 & Mencari sumber materi ajar & 29 & 32,58 & Rendah \\
\hline
\end{tabular}

Data menunjukkan bahwa prosentase siswa tertinggi pada indicator mengumpulkan tugas tepat waktu $(80,90 \%)$. Sedangkan indikator terendah pada review materi pembelajaran $(46,07 \%)$ dan mencari sumber ajar $(32,58 \%)$.

\section{Kendala yang Dihadapi Siswa dalam Pembelajaran PAI Menggunakan Zoom}

Pembelajaran daring merupakan model pembelajaran yang dalam aktivitasnya memanfaatkan jaringan internet dengan aksesibilitas, konektivitas, fleksibilitas, dan kemampuan untuk memunculkan berbagai jenis interaksi pembelajaran (Sadikin \& Hamidah, 2020). Pembelajaranan daring dilakukan dengan memanfaatkan teknologi internet dengan sistem belajar jarak jauh, sehingga kegiatan belajar dan mengajar (KBM) tidak dilakukan secara tatap muka.

Pembelajaran PAI dengan memanfaatkan aplikasi Zoom tentunya memiliki kelemahan atau kendala yang harus dihadapi siswa dalam pembelajaran. Untuk mengetahui apa saja kendala yang dihadapi siswa dlam pembelajaran PAI dilakukan survei kepada 89 siswa. Hasilnya dilaporkan sebagai berikut: 
2966 Efektivitas Penggunaan Aplikasi Zoom Meeting dalam Pembelajaran PAI di Masa Pandemi Covid-19Novita, Muhamad Taufik Bintang Kejora, Akil

DOI: https://doi.org/10.31004/edukatif.v3i5.1070

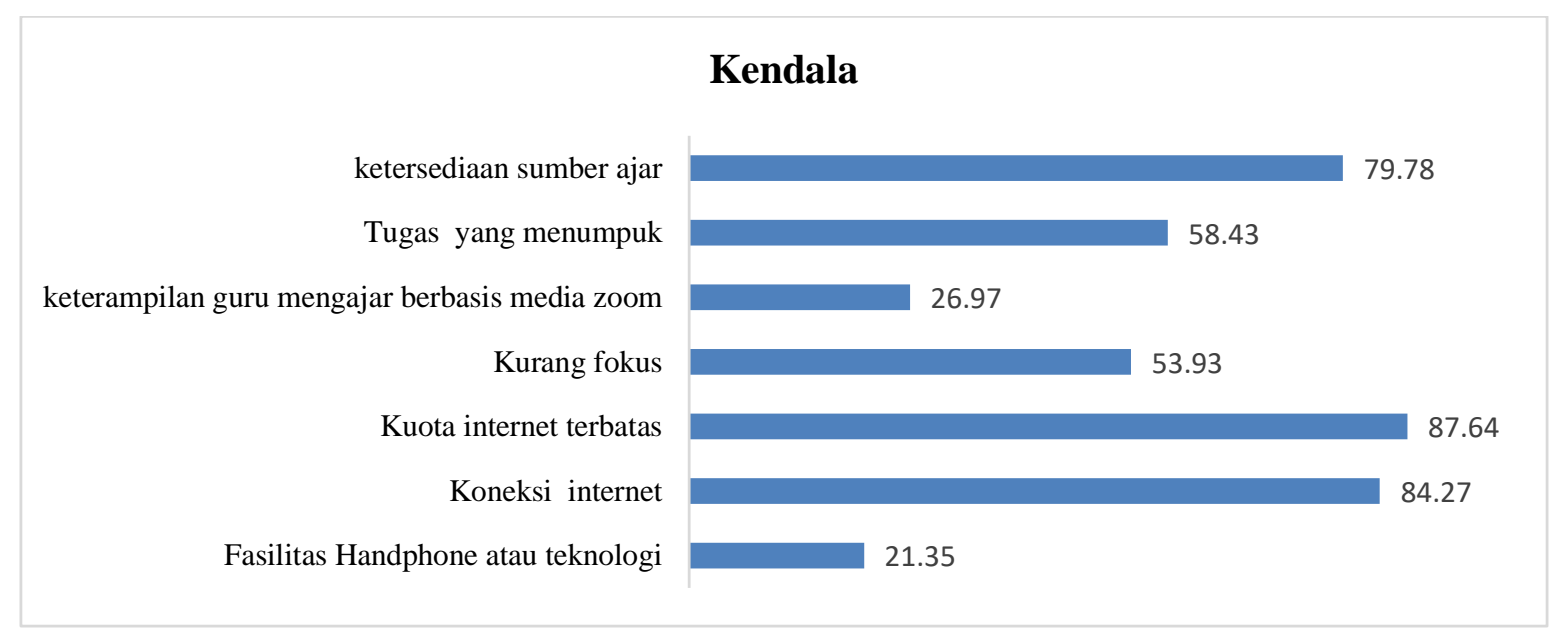

Gambar 1. Kendala yang Dihadapi Siswa

Berdasarkan survei, respon siswa mengenai hambatan yang dialami selama pembelajaran PAI secara daring memanfaatkan Zoom menunjukkan hambatan yang dihadapi banyak siswa adalah pada kuota internet, koneksi internet, dan ketersediaan sumber ajar. Dari hasil survei juga diketahui bahwa fasilitas handphone atau perangkat pembelajaran yang dimiliki cukup memadai. Hanya $26 \%$ siswa yang menilai aspek keterampilan IT guru sebagai hambatan, artinya kemampuan guru mengajar dengan aplikasi zoom pun diklaim mendukung pembelajaran. Hasil penelitian ini sejaan dengan hasil penelitian (Kelana et al., 2021) kesulitan dalam pelaksanaan pembeajaran dengan Zoom, diantaranya: kurang memadainya sarana dan prasarana, koneksi internet yang terganggu, penggunaan kuota internet yang boros dan guru/dosen tidak bisa mengontrol siswa secara penuh.

\section{Hasil belajar dan Tingkat Kepuasan Siswa terhadap Pembelajaran PAI Secara Daring Memanfaatkan Zoom}

Pengumpulan data berikutnya menangani hasil belajar siswa dalam pembelajaran PAI menggunakan Zoom. Hasil belajar adalah alat bantu yang membimbing siswa untuk hasil yang diinginkan dari pembelajaran yang direncanakan. Hasil belajar juga menunjukkan dan membantu para guru jalan yang harus diikuti dan membuat siswa menyadari apa yang akan mereka capai di akhir pemebelajaran. Mereka juga membantu para guru dan siswa mengetahui rute yang harus dilalui (Mahajan \& Singh, 2017). Hasil belajar adalah pernyataan tentang apa yang diharapkan untuk diketahui, dipahami, dan/atau dapat didemonstrasikan oleh pembelajar setelah menyelesaikan suatu proses belajar. Lebih jelasnya, hasil belajar adalah pernyataan tertulis tentang apa yang diharapkan dapat dicapai oleh siswa/peserta didik yang berhasil di akhir modul program/unit kursus atau kualifikasi (Paolini, 2015). Hasil belajar merupakan hal penting bagi guru sebagai landasan menentukan tindak lanjut dan perbaikan. Sedangkan bagi siswa memberikan deskripsi mengenai kompetensi apa saja yang dapat dikuasai siswa dari sebuah pembelajaran.

Pada pembelajaran PAI di kelas VIII SMPN 2 Pasawahan, KKM (Kriteria Ketuntasan Minimal) ditetapkan pada nilai 75. Berdasarkan KKM tersebut, disusunlah standar penilaian sebagai berikut:

Tabel 5. KKM PAI

\begin{tabular}{cccc}
\hline No & Rentang Nilai & Interprestasi & Simbol \\
\hline 1. & $<75$ & Kurang & D \\
\hline 2. & $75-83,33$ & Cukup & C \\
\hline 3. & $83,34-91,67$ & Baik & B \\
\hline 4. & $91,68-100$ & Sangat Baik & A \\
\hline
\end{tabular}


2967 Efektivitas Penggunaan Aplikasi Zoom Meeting dalam Pembelajaran PAI di Masa Pandemi Covid-19Novita, Muhamad Taufik Bintang Kejora, Akil

DOI: https://doi.org/10.31004/edukatif.v3i5.1070

Berdasarkan pengumpulan data, hasil belajar siswa kelas VIII pada pelajaran PAI memanfaatkan Zoom sebagai berikut:

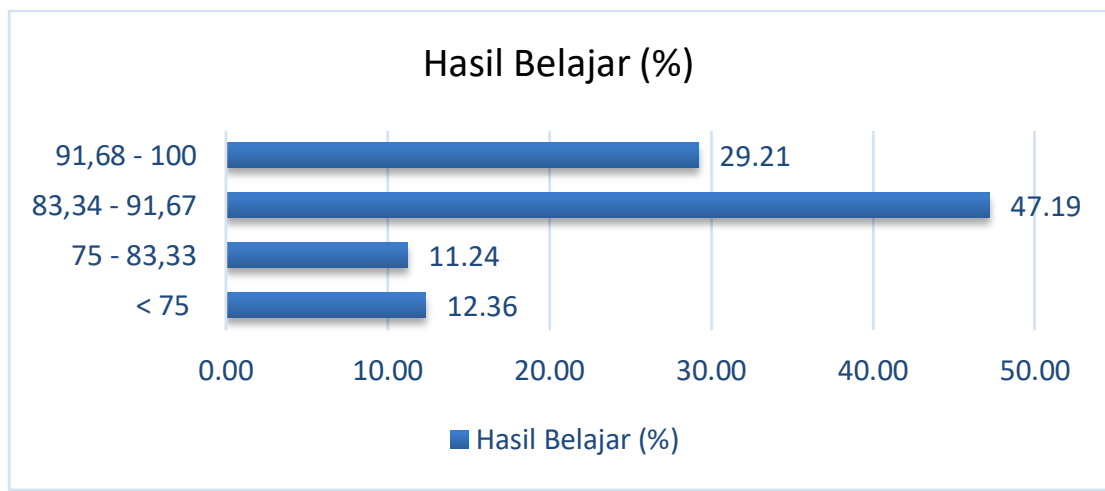

Gambar 2. Prosentase Perolehan Hasil Belajar Siswa

Berdasarkan data, rata-rata hasil belajar siswa secara kumulatif atau klasikal 85.72 menunjukkan hasil belajar siswa dalam pembelajaran daring menggunkan Zoom pada pembelajaran PAI dalam kategori baik. Terdapat 11 siswa $(12,36 \%)$ dengan nilai dibawah KKM, 10 siswa $(11,24 \%)$ dengan nilai cukup, 42 siswa $(47,12 \%)$ dengan nilai baik, dan 26 siswa $(29,21 \%)$ dengan nilai sangat baik.

Selanjunya yang tidak kalah penting adalah kepuasan siswa terhadap pembelajaran PAI secara daring memanfaatkan Zoom. Pengumpulan data menggunakan survei dan hasilnya sebaagai berikut:

Tabel 6. Kepuasan Siswa

\begin{tabular}{lcc}
\hline Respon Kepuasan Siswa & Jumlah Siswa & \% \\
\hline Sangat Puas & 35 & 39,33 \\
\hline Puas & 33 & 37,08 \\
\hline Kurang Puas & 11 & 12,36 \\
\hline Tidak Puas & 10 & 11,23596 \\
\hline & 89 & 100 \\
\hline
\end{tabular}

Hasil survei kepuasan siswa menunjukkan jumlah siswa yang merespon sangat puas dan puas berjumlah 68 orang dengan prosentase $(76,40 \%)$. Artinya siswa merasa puas terhadap pembelajaran PAI secara daring memanfaatkan Zoom. Merujuk pada hasil penelitian Mannong (2020), pemanfaatan aplikasi digital dapat menjadikan pembelajaran anatara guru dengan siswa atau siswa yang satu dengan siswa lainnya menjadi aktif, interaktif dan efektif manakala didukung dengan fasilitas yang menunjang, desain materi ajar yang manarik dan tidak membosankan, variative dalam gaya mangajar, memberi penekanan kedisiplinan kepada siswa, dan membangkitkan kesadaran siswa pentingnya belajar (Kejora, 2020). Siswa dibimbing secara inquiry dan discovery dengan cara-cara yang menyenangkan dan kreatif sehingga dalam mencapai tujuan pembelajaran, siswa merasakan kebersamaan dan menyenangkan (Taufik, 2020).

Hasil penelitian ini, dapat dijadikan learning evaluation (evaluasi pembelajaran) bagi guru Pendidikan Agama Islam dan pengambil kebijakaan di sekolah dalam membuat perencanaan, mendesain pembelajaran, dan merancang evaluasi pembelajaran sehingga memberi pertimbangan dalam mengambil treatment perbaikan yang tepat bagi optimalisasi pembelajaran. Kendati dalam beberapa hal, penelitiaan ini berupaya menyajikan data dan hasil yang optimal, namun tentunya penelitian ini juga masih terdapat keterbatasan dan kelemahan. Diharapkan penelitian selanjutnya dapat dilakukan dengan cakupan subjek dan lokasi penelitian lebih luas lagi, sehingga hasil generalisasi tidak hanya sebatas subjek dalam penelitian ini saja, yang jumlahnya masih 
2968 Efektivitas Penggunaan Aplikasi Zoom Meeting dalam Pembelajaran PAI di Masa Pandemi Covid-19Novita, Muhamad Taufik Bintang Kejora, Akil

DOI: https://doi.org/10.31004/edukatif.v3i5.1070

sangat terbatas. Sehingga diperlukan kajian penelitiaan dengan cakupan aspek dan indikator yang juga lebih mendalam sehingga hasil peneitian lebih komprehensif dan bernilai guna.

\section{KESIMPULAN}

Pembelajaran PAI di masa pandemic perlu beradaptasi dengan perubahan dan arah kebijakan yang mendorong berlakunya pembelajaran jarak jauh secara online atau daring. Platform Zoom pun menjadi media pilihan yang dianggap mampu memfasilitasi belajar siswa selama diberlakukannya belajar dari rumah. Keterampilan guru dalam mengoperasikan media, menstimulus keterampilan berpikir melalui bertanya, dan menjelaskan pembelajaran menjadi kunci keberhasilan. Didukung dengan keterampilan lainnya yang menjadikan pembelajaran semakin bermakna. Dalam pembelajaran berbasis Zoom, perlu ditingkatkan kemampuan siswa dalam mereview kembali pembelajaran dan kemampuan mencari sumber ajar dari internet atau sumber lainnya. Kendala umum yang dihadapi siswa tentunya perlu ditemukan solusinya mencakup kuota internet, koneksi internet, dan ketersediaan sumber ajar. Meski terdapat kendala dan kekurangan dalam proses pembelajaran, namun fakta lain menggambarkan bahwa hasil belajar siswa tercapai dengan baik. Siswa pun merasa puas dengan pembelajaran yang mereka jalani selama pembelajaran daring berbasis Zoom. Dengan demikian dapat disimpulkan bahwa aplikasi Zoom menjadikan pembelajaran PAI secara daring lebih efektif dalam mencapai tujuan pembelajaran.

\section{DAFTAR PUSTAKA}

Asmawati, E., \& Bintang Kejora, M. T. (2020). The Effect Of Using Simple Aircraft Concrete Media On The Mastery Of Concepts In Inquiry Science Learning In Elementary School Students. MUDARRISA: Jurnal Kajian Pendidikan Islam, 12(2), 150-168. Https://Doi.Org/10.18326/Mdr.V12i2.150-168

Bawanti, P. K. D., \& Arifani, Y. (2021). The Students' Perceptions Of Using Zoom Application On Mobile Phone In Improving Speaking Skills During Online Learning At Ban Loeiwangsai School, Loei Province, Thailand. Journal Of English Teaching, Literature, And Applied Linguistics, 5(1), 54. Https://Doi.Org/10.30587/Jetlal.V5i1.2212

Bilda, W., \& Fadillah, A. (2020). An Analysis Of Students In Independent Learning Of Analytic Geometry During The COVID-19 Pandemic. JTAM (Jurnal Teori Dan Aplikasi Matematika), 4(2), 166. Https://Doi.Org/10.31764/Jtam.V4i2.2575

Butnaru, G. I., Niță, V., Anichiti, A., \& Brînză, G. (2021). The Effectiveness Of Online Education During Covid 19 Pandemic - A Comparative Analysis Between The Perceptions Of Academic Students And High School Students From Romania. Sustainability (Switzerland), 13(9). Https://Doi.Org/10.3390/Su13095311

Dong, C., Cao, S., \& Li, H. (2020). Young Children's Online Learning During COVID-19 Pandemic: Chinese Parents' Beliefs And Attitudes. Children And Youth Services Review, 118(1), 1-24. Https://Doi.Org/10.1016/J.Childyouth.2020.105440

Farfar, G. (2021). Efektifitas Penggunaan Aplikasi Zoom Meeting Dalam Pembelajaran. ISTORIA: Jurnal Pendidikan Dan Sejarah, 17(1).

Guzacheva. (2020). Zoom Technology As An Effective Tool For Distance Learning. Bulletin Of Science And Practice, 6(5), 457-460.

Kejora, M. T. B. (2020). The Use Of Concrete Media In Science Learning In Inquiry To Improve Science Process Skills For Simple Machine Subject. MUDARRISA: Jurnal Kajian Pendidikan Islam, 12(1), 117. Https://Doi.Org/10.18326/Mdr.V12i1.1-17

Kelana, J. B., Wulandari, M. A., \& Wardani, D. S. (2021). Penggunaan Aplikasi Zoom Meeting Di Masa 
2969 Efektivitas Penggunaan Aplikasi Zoom Meeting dalam Pembelajaran PAI di Masa Pandemi Covid-19Novita, Muhamad Taufik Bintang Kejora, Akil

DOI: https://doi.org/10.31004/edukatif.v3i5.1070

Pandemi Covid-19. Jurnal Elementary, 4(1), 18-22.

Lubis, M., Yusri, D., \& Media Gusman. (2020). Pembelajaran Pendidikan Agama Islam Berbasis E-Learning. Pembelajaran Pendidikan Agama Islam Berbasis E-Learning (Studi, 1(1), 1-18. Http://Jurnal.Staisumatera-Medan.Ac.Id/Index.Php/Fitrah

Mahajan, M., \& Singh, M. K. S. (2017). Importance And Benefits Of Learning Outcomes. IOSR Journal Of Humanities And Social Science, 22(03), 65-67. Https://Doi.Org/10.9790/0837-2203056567

Mannong, A. B. M. (2020). The Students' Eyesight: The Effectiveness Of Learning-Based Applications On Elt In Pandemic Era. ETERNAL (English, Teaching, Learning, And Research Journal), 6(2), 394. Https://Doi.Org/10.24252/Eternal.V62.2020.A14

Minhas, S., Hussain, T., Ghani, A., Sajid, K., \& Pakistan, L. (2021). Exploring Students Online Learning: A Study Of Zoom Application. Gazi University Journal Of Science , 34(2), 171-178. Https://Doi.Org/10.35378/Gujs.691705

Monica, J., \& Fitriawati, D. (2020). Efektivitas Penggunaan Aplikasi Zoom Sebagai Media Pembelajaran Online Pada Mahasiswa Saat Pandemi Covid-19. Jurnal Communio : Jurnal Jurusan Ilmu Komunikasi, 9(2), 1630-1640. Https://Doi.Org/10.35508/Jikom.V9i2.2416

Nguyen, V. A. (2017). The Impact Of Online Learning Activities On Student Learning Outcome In Blended Learning Course. Journal of Information And Knowledge Management, 16(4). Https://Doi.Org/10.1142/S021964921750040X

Paolini, A. (2015). Enhancing Teaching Effectiveness And Student Learning Outcomes. The Journal Of Effective Teaching, 15(1), 20-33.

Patacsil, F. F., \& Tablatin, C. L. S. (2017). Exploring The Importance Of Soft And Hard Skills As Perceived By It Internship Students And Industry: A Gap Analysis. Journal Of Technology And Science Education, 7(3), 347-368. Https://Doi.Org/10.3926/Jotse.271

Puspita Sari, A., \& Setiawan, A. (2018). The Development Of Internet-Based Economic Learning Media Using Moodle Approach. International Journal of Active Learning, 3(2), 100-109. Http://Journal.Unnes.Ac.Id/Nju/Index.Php/Ijal

Putra, P., Liriwati, F. Y., Tahrim, T., Syafrudin, S., \& Aslan, A. (2020). The Students Learning From Home Experiences During Covid-19 School Closures Policy In Indonesia. Jurnal Iqra': Kajian Ilmu Pendidikan, 5(2), 30-42. Https://Doi.Org/10.25217/Ji.V5i2.1019

Rahayu, M. M. (2015). Pengaruh Kebiasaan Belajar Terhadap Hasil Belajar Matematika. Journal Of Elementary Education, 4(1), 39-45.

Sadikin, A., \& Hamidah, A. (2020). Pembelajaran Daring Di Tengah Wabah Covid-19. Biodik, 6(2), 109-119. Https://Doi.Org/10.22437/Bio.V6i2.9759

Salam, U. (2020). The Students' Use Of Google Classroom In Learning English. JPI (Jurnal Pendidikan Indonesia), 9(4), 628-638. Https://Doi.Org/10.23887/Jpi-Undiksha.V9i4.27163

Setiawan, B., Sofyan Rofi, \& Tri Endang Jatmikowati. (2021). The Student Learning Activity Levels On The Online Learning During The Covid-19 Pandemic. Jurnal Pendidikan Islam Indonesia, 5(2), 186-197. Https://Doi.Org/10.35316/Jpii.V5i2.289

Sögüt, S., Dolu, İ., \& Cangöl, E. (2021). The Relationship Between COVID-19 Knowledge Levels And Anxiety States Of Midwifery Students During The Outbreak: A Cross-Sectional Web-Based Survey. Perspectives In Psychiatric Care, 57(1), 246-252. Https://Doi.Org/10.1111/Ppc.12555

Suardi, M. (2020). The Effectiveness Of Using The ZOOM Cloud Meetings Application In The Learning Process. Proceeding Of The International Conference On Science And Advanced Technology (ICSAT), 590-602.

Taufik, M. (2020). Strategic Role Of Islamic Religious Education In Strengthening Character Education In 
2970 Efektivitas Penggunaan Aplikasi Zoom Meeting dalam Pembelajaran PAI di Masa Pandemi Covid-19Novita, Muhamad Taufik Bintang Kejora, Akil

DOI: https://doi.org/10.31004/edukatif.v3i5.1070

The Era Of Industrial Revolution 4.0. Jurnal Ilmiah Islam Futura, 20(1), 86. Https://Doi.Org/10.22373/Jiif.V20i1.5797

Waryani. (2021). Dinamika Kinerja Guru Dan Gaya Belajar (Konsep Dan Implementasi Terhadap Prestasi Belajar). CV. Adanu Abimata. 